九州大学学術情報リポジトリ

Kyushu University Institutional Repository

Microspectrophotometrical Studies of the Hypophysis in the Domestic Fowl (Gallus domesticus) : III. Variation of PAS Positive Materials Contained in the Adenohypophysis of White Leghorn Cocks Following the Hypothalamic Lesion

Takahara, Hitoshi

Laboratory of Animal Husbandry II, Faculty of Agriculture, Kyushu University

https://doi.org/10.5109/23712

出版情報: 九州大学大学院農学研究院紀要. 24 (4)，pp.223-237，1980-02. Kyushu University バージョン：

権利関係 : 


\title{
Microspectrophotometrical Studies of the Hypophysis in the Domestic Fowl (Gallus domesticus)

\author{
III. Variation of PAS Positive Materials Contained in the \\ Adenohypophysis of White Leghorn Cocks Following \\ the Hypothalamic Lesion
}

\author{
Hitoshi Takahara \\ Laboratory of Animal Husbandry II, Faculty of Agriculture, \\ Kyushu University 46-06, Fukuoka 812
}

(Received November 13, 1979)

\begin{abstract}
It is well recognized that gonadotropic function of the adenohypophysis is regulated by the hypothalamus in the domestic fowl. The present study deals with cytological changes of the adenohypophysis and the quantitative variation of PAS positive contents in the gland following the hypothalamic lesion in the White Leghorn cocks. Adenohypophysis, testes and the accessory organ weights were markedly decreased after the electrolytic lesion involving the basal tuberal or posterior median eminence region of the hypothalamus. Obvious cytological degeneration of basophils in the adenohypophysis was also observed in these cocks, and PAS positive contents in the cytoplasm of the cell were decreased significantly in microspectrophotometrical measurement. It is concluded from these results and the atrophic state of gonadal organs that the gonadotropic hormone output from the hypophysis after the injury of basal tuberal or posterior median eminence region must be at a very low level in consequence of disruption or at least great impairment of neural and vascular connexions between adenohypophysis and the hypothalamus.
\end{abstract}

\section{INTRODUCTION}

There are many peculiar problems on the structure and function of the domestic fowl adenohypophysis. Like other physiological processes, the gonadotropic functions of the adenohypophysis are deeply influenced by external as well as internal environmental factors. The present knowledge on the reproductive function and structural relationship to the hypothalamo-hypophyseal system throws some light on the detection of the control mechanism of the adenohypophyseal function by the superior regulating centers in the domestic fowl.

It is well known that basophils contain a large amount of glycoproteins in the adenohypophysis in mammals. Catchpole (1949) and Purves and Griesbach (1951) stated these basophils were stained strongly with PAS reaction in the rat adenohypophysis. Halmi $(1950,1952)$ and Purves and Griesbach (1951, 1955) separated these basophils into gonadotrophs and thyrotrophs, and Purves and Griesbach (1954) stated that gonadotrophs were divided into two types, FSH and LH secreting cells. In the fowl adenohypophysis, Wilson 
(1952), Yasuda (1953) and Mikami (1958) classified the basophils into two separate types, gonadotrophs and thyrotrophs, but no cytological evidences were found to support the differentiation FSH and LH secreting cells in gonadotrophs.

It is an important problem to get an exact value of hormone content in each cell of gonadotrophs in the adenohypophysis. A number of cytochemical reactions are used for indicating glycoprotein and most of them are variants of the periodic acid Schiff (PAS) reaction, introduced independently by Hotchkiss (1948) and McManus (1948). The basis for the reaction is the formation of aldehyde through oxidation of hydroxyl groups by periodic acid, and the subsequent coupling of the Schiff reagent to aldehyde. It has been obtained by measuring the glycoprotein contents in each cell directly by estimating with microspectrophotometry.

The PAS reaction has been studied with a variety of substances in solutions (McManus and Hoch-Ligeti, 1952; Neumiller and Vasseur, 1953; Fand and Thorell, 1962; Dahlqvist et al., 1965), and the reaction was shown to be stoichiometric, i.e. the absorption of light followed Beer's law (Gahrton and Yataganas, 1976). There is thus a theoretical basis for studies aimed at clarifying whether the reaction is also quantitative on the cytochemical level.

The present study deals with quantitative variation of glycoprotein contained in the basophils of the fowl adenohypophysis following the hypothalamic lesion, and attempted to clarify the hypothalamic control of hypophyseal gonadotropic functions.

\section{MATERIALS AND METHODS}

Middle single or bilateral electrolytic lesions were produced stereotaxically in the hypothalamus or some other parts of the brain in the White Leghorn cocks at 20 weeks of age (Fig. 1 and Table 1). Each lesion was made passing $2 \mathrm{~mA} \mathrm{DC}$ for 20 seconds in most cases and $3 \mathrm{~mA} \mathrm{DC}$ for 30 seconds in a few cases through the brain. Mock lesioned birds differed from the other birds only in that no current was passed when the electrodes were in position. Autopsy was performed at 8-9 weeks later following the production of hypothalamic lesion.

\section{Cytological and cytochemical methods}

Brains were carefully dissected out, fixed in $10 \%$ formalin, $20 \mu$ thick frozen sections were made using the cryotom and stained with thionine. The location of lesions was ascertained by observing the fresh brains under a dissecting apparatus and by making graph paper reconstructions of brain sections. The adenohypophysis was fixed in sublimate-formol, embedded in paraffin, sectioned at $5 \mu$ thick, and stained with Matsuo tetrachrome method (Matsuo, 1954), PAS-Matsuo tetrachrome method or PAS-Heidenhain's iron hematoxylin for cytological observation, and with PAS staining method (McManus, 1948) for quantitative cytochemistry. 


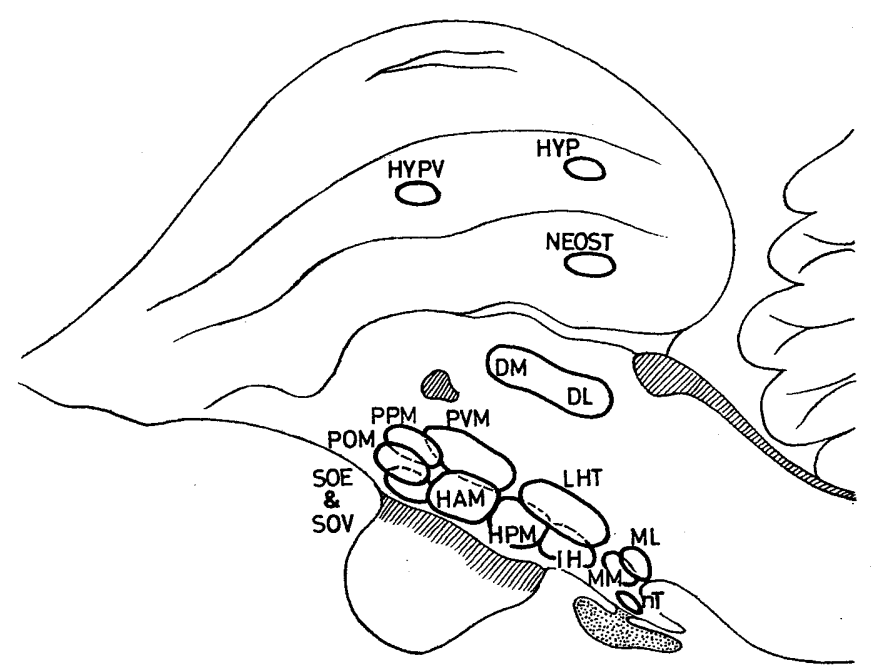

Fig. 1. Site of hypothalamic or extrahypothalamic lesion in the brain of the White Leghorn cock (half schematic). POM; nucleus praeopticus medialis, PVM; nucl. paraventricularis magnocellularis, PPM; nucl. praeopticus paraventricularis, SOV ; nucl. supropticus ventralis, SOE ; nucl. supraopticus externus, HAM; nucl. hypothalmicus anterior medialis, HPM; nucl. hypothalamicus posterior medialis, IH; nucl. hypothalamicus inferior, LHT; nucl. hypothalamicus lateralis, $\mathrm{nT}$ : nucl. tuberis, MM; nucl. mammilaris medialis, ML; nucl. mammilaris lateralis, DM; nucl. dorsomedialis, DL; nucl. dorsolateralis, HYPV; Hyperstriatum ventrale, HYP; Hyperstriatum, NEOST; Neostriatum.
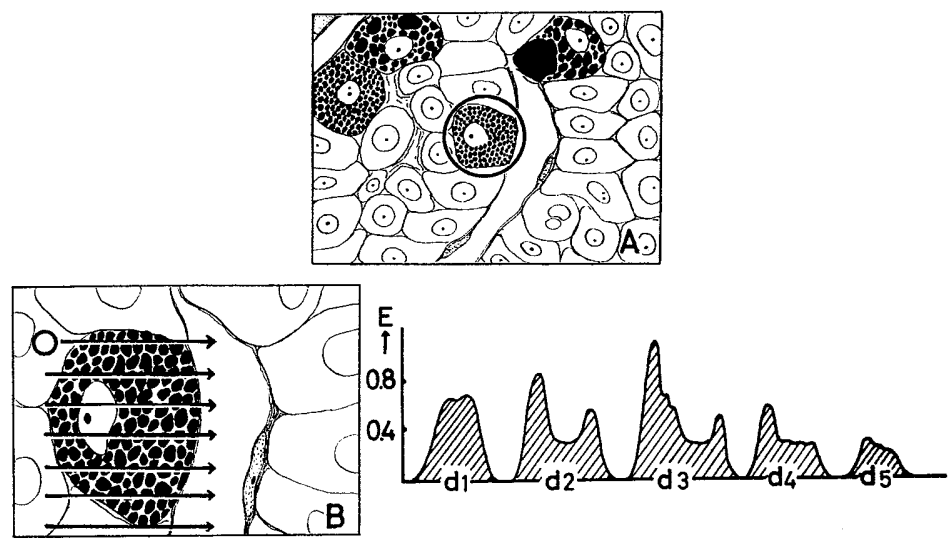

Fig. 2. Aspects of microspectrophotometrical measurements in this study. $A$, two-wavelength method; B, scanning method (left side) and its absorption curve (right side).

\section{Microspectrophotometrical method}

Measurements were made using an apparatus, Olympus Microspectrophotometer-Model, MSP-AIV. Two procedures were applied for measurements to avoid distributional errors in the same experiment. One is the Two-wave- 
length method (Ornstein, 1952; Patau, 1952-Fig. 2A) and another is the scanning method (Utsumi and Seno, 1960-Fig. 2B).

A) Two-wavelength measurement

Calculation formula of two-wavelength method can be stated in the following equation;

$$
r=K B L_{1} C \quad \text { (Patau's formula) }
$$

where, $\gamma$; total amount of PAS positive materials, $K$; a constant, $B$; light spot area, $L_{1} C$; relative amount of chromophore in the field, $C=\frac{1}{2-Q} \ln \frac{1}{Q-1}$,

$Q=\frac{L_{2}}{L_{1}}, \quad L_{1}=1-T_{1}, \quad L_{2}=1-T_{2}, T_{n} ;$ transmittancy. Measurement areas were constantly decided $314 \mu^{2}$ by using a pinhole No. 1.0, resulted to light up the spot $10.0 \mu$ in diameter (P1. V1-Fig. 6). Tables were used to facilitate the calculations (Mendelsohn, 1958).

B) Scanning measurement

Calculation formula of the scanning method can be stated in the following equations;

$$
\begin{aligned}
& C_{\mathrm{PAS}}^{\prime}=S \cdot \frac{1}{\sum_{i=1}^{n} d i} \sum \int_{0}^{d} f(x) d x \cdots \cdots \text { in arbitrary unit } \\
& C_{\mathrm{PAS}}=K \cdot S \cdot \frac{1}{\sum_{i=1}^{n} d i} \sum \int_{0}^{d} f(x) d x \cdots \cdots \text { in absolute unit }
\end{aligned}
$$

where, $C_{\mathrm{PAS}}$; total amount of PAS positive materials, $K$; a constant derived from the standard curve, $S$; cell area $\left(\sum_{i=1}^{n} d i\right), d i$; width of the cytoplasm of the cell, $f(x)$; the curve obtained actually tracing the PAS positive materials with the light spot, $\frac{1}{\sum_{i=1}^{n} d i} \sum \int_{0}^{d} f(x) d x$; optical density. Size of the scanning light spot was constantly decided to $1.6 \mu$ in diameter.

Measurements were always taken place about 30 basophils throughout the middle sagittal plane of each adenohypophysis, and the average value was obtained.

\section{RESULTS}

\section{Cytological and cytochemical observations}

After the electrolytic injury of the basal tuberal (nT) or posterior median eminence region (MM and $\mathrm{ML}$ ) of the hypothalamus marked decreases were noticed in the weight of the adenohypophysis, testes and comb (Table 1). On the contrary, the weight of body, liver and abdominal fat were signifi- 
Table 1. Effects of hypothalamic lesion on the weight of body, adenohypophysis, thyroids, adrenals, testes, comb, liver and abdominal fat in cocks.

\begin{tabular}{|c|c|c|c|c|c|c|c|c|c|}
\hline Site of le & $\begin{array}{c}\text { Number } \\
\text { of } \\
\text { birds }\end{array}$ & $\begin{array}{l}\text { Body } \\
\text { weight } \\
\text { (kg) }\end{array}$ & $\begin{array}{c}\text { Adenohypo } \\
\text { physis } \\
\text { wt. } \\
(\mathrm{mg} / \mathrm{kg})\end{array}$ & $\begin{array}{c}\text { Thyroids } \\
\text { wt. } \\
(\mathrm{mg} / \mathrm{kg})\end{array}$ & $\begin{array}{c}\text { Adrenals } \\
\text { wt. } \\
(\mathrm{mg} / \mathrm{kg})\end{array}$ & $\begin{array}{c}\text { Testes } \\
\text { wt. } \\
(\mathrm{g} / \mathrm{kg})\end{array}$ & $\begin{array}{c}\text { Comb } \\
\text { wt. } \\
(\mathrm{g} / \mathrm{kg})\end{array}$ & $\begin{array}{c}\text { Liver } \\
\text { wt. } \\
(\mathrm{g} / \mathrm{kg})\end{array}$ & $\begin{array}{l}\text { Abdo- } \\
\text { minal } \\
\text { fat wt. } \\
(\mathrm{g} / \mathrm{kg})\end{array}$ \\
\hline $\begin{array}{l}\text { POM } \\
\text { PVM } \\
\text { PPM } \\
\text { SOV \& SOE } \\
\text { HAM } \\
\text { HPM } \\
\text { IH } \\
\text { LHT } \\
\text { nT } \\
\text { MM } \\
\text { ML \& DL } \\
\text { DM \& DL } \\
\text { Ext. H. } \\
\text { Mock lesioned } \\
\text { Controls }\end{array}$ & $\begin{array}{r}7 \\
6 \\
4 \\
7 \\
4 \\
5 \\
6 \\
7 \\
14 \\
10 \\
8 \\
5 \\
6 \\
19 \\
28\end{array}$ & $\begin{array}{l}1.953 \\
2.003 \\
1.890 \\
1.958 \\
1.958 \\
2.335^{11} \\
1.809 \\
2.289^{11} \\
2.293^{11} \\
2.315^{11} \\
2.120 \\
2.105 \\
2.027 \\
1.982\end{array}$ & $\begin{array}{l}6.01 \\
5.90 \\
5.65 \\
5.61 \\
5.83 \\
5.82 \\
5.30 \\
5.96 \\
4.05^{11} \\
4.071 \\
3.50^{11} \\
4.98 \\
5.02 \\
5.65 \\
5.97\end{array}$ & $\begin{array}{l}66.00 \\
62.14 \\
78.90 \\
53.50^{23} \\
65.97 \\
64.66 \\
69.84 \\
68.93 \\
64.99 \\
75.08 \\
59.58 \\
70.32 \\
71.26\end{array}$ & $\begin{array}{l}78.83 \\
74.78 \\
80.47 \\
82.84 \\
79.56 \\
68.82 \\
77.94 \\
75.23 \\
71.85 \\
62.18^{2)} \\
70.62 \\
76.88 \\
86.23 \\
80.99\end{array}$ & $\begin{array}{l}4.34 \\
5.47 \\
3.93 \\
2.54^{22} \\
5.98 \\
5.36 \\
6.58 \\
4.64 \\
2.86^{2)} \\
1.10^{11} \\
0.30^{11} \\
4.64 \\
3.93 \\
6.98 \\
5.37\end{array}$ & $\begin{array}{l}33.80 \\
32.60 \\
30.60 \\
38.23 \\
44.33 \\
34.16 \\
25.80^{1)} \\
26.51^{2)} \\
18.32^{11} \\
19.75^{1)} \\
9.38^{1)} \\
41.42 \\
40.52 \\
39.48 \\
38.10\end{array}$ & $\begin{array}{l}15.80 \\
17.20 \\
16.23 \\
15.57 \\
15.55 \\
14.08 \\
15.25 \\
18.96^{2)} \\
25.26^{1)} \\
25.82^{1)} \\
31.46^{1)} \\
16.28 \\
13.22 \\
17.58 \\
16.65\end{array}$ & $\begin{array}{c}15.50^{1)} \\
9.80^{2)} \\
7.50 \\
1.69 \\
5.40 \\
3.80 \\
10.55^{2)} \\
4.94 \\
43.31^{1)} \\
44.49^{11} \\
66.91^{11} \\
2.02 \\
0.20 \\
2.86 \\
3.85\end{array}$ \\
\hline
\end{tabular}

1) Significant at $1 \%$ level. 2) Significant at $5 \%$ level.

cantly increased following the lesion of the same parts. It appears that the inhibition of gonadotropic activity in the adenohypophysis occurred by the hypothalamic lesion in these parts resulting to gonadal atrophy and obesity.

Pars distalis of the adenohypophysis in the domestic fowl is divided clearly into two parts, cephalic and caudal lobes. Four basic cell types, the acidophils, basophils, amphophils and chromophobes have been identified in the pars distalis by means of Matsuo tetrachrome and PAS-Heidenhain's iron hematoxylin staining methods (Pl. VI-Figs. 1 and 3). The basophils are stained by methyl green with Matsuo tetrachrome method and they are PAS positive (P1. VI-Fig. 4).

Two types of basophils, light and deep, can be distinguished with PASMatsue tetrachrome stain. Light basophils are the largest cell type observed in both lobes of the pars distalis. They are round or oval with clearly defined cell boundaries. Their nuclei are large and light with distinct nucleoli. The cytoplasm is light, containing only a few granules stained with methyl green. These cells are positive to PAS reaction.

Deep basophils are polyhedral or oval and usually much smaller than the light basophils. They are found in both lobes of the pars distalis. The cytoplasmic granules of these cells are coarse and have a strong affinity for methyl green stains. These cells show a stronger PAS positive reaction than the light basophils.

Basophil cell percentage was obtained in the middle sagittal section of the adenohypophysis following the hypothalamic lesion to get the relative amount of glycoprotein by microspectrophotometry (Table 2).

When the PAS reaction was applied to adenohypophysis, basophils in both cephalic and caudal lobes were strongly positive to PAS reaction in the control and mock lesioned cocks (P1. VI-Fig. 4). Amphophils in the cephalic 
Table 2. Variation of percentage of four basic cell types occupied in the middle sagittal plane of the adenohypophysis following the hypothalamic lesion.

\begin{tabular}{|c|c|c|c|c|c|c|}
\hline \multirow{2}{*}{$\begin{array}{l}\text { Site of } \\
\text { lesion }\end{array}$} & \multicolumn{3}{|c|}{ Basophils (\%) } & \multirow{2}{*}{$\begin{array}{l}\text { Acidophils } \\
\text { (\%) }\end{array}$} & \multirow{2}{*}{$\begin{array}{c}\text { Amphophils } \\
\text { (\%) }\end{array}$} & \multirow{2}{*}{$\begin{array}{l}\text { Chromo- } \\
\text { phobes } \\
(\%)\end{array}$} \\
\hline & Light & Deep & Total & & & \\
\hline $\begin{array}{l}\text { PPM } \\
\text { HPM } \\
\text { nT } \\
\text { MM } \\
\text { Ext. H. } \\
\text { Controls }\end{array}$ & $\begin{array}{l}6.31 \pm 1.12 * \\
5.64 \pm 0.73 \\
6.06 \pm 0.70 \\
4.59 \pm 0.22 \\
7.12 \pm 0.83 \\
5.00 \pm 0.39\end{array}$ & $\begin{array}{l}31.47 \pm 2.40 * \\
20.78 \pm 1.04 \\
21.57 \pm 1.86 \\
16.72 \pm 2.60 \\
32.13 \pm 2.51 \\
30.04 \pm 2.03\end{array}$ & $\begin{array}{l}37.78 \pm 3.04 * \\
26.42 \pm 1.82 \\
27.63 \pm 1.96 \\
21.31 \pm 2.27 \\
39.25 \pm 1.85 \\
35.04 \pm 1.92\end{array}$ & $\begin{array}{l}4.89 \pm 0.76^{*} \\
4.09 \pm 0.46 \\
4.88 \pm 0.38 \\
4.43 \pm 0.66 \\
5.09 \pm 0.54 \\
4.61 \pm 0.82\end{array}$ & $\begin{array}{l}6.50 \pm 0.53 * \\
5.79 \pm 0.86 \\
9.39 \pm 0.91 \\
6.83 \pm 0.90 \\
7.42 \pm 0.94 \\
5.73 \pm 0.72\end{array}$ & $\begin{array}{l}50.83 \pm 3.37 * \\
63.70 \pm 2.08 \\
58.10 \pm 1.75 \\
67.43 \pm 2.04 \\
48.24 \pm 1.45 \\
54.62 \pm 3.09\end{array}$ \\
\hline
\end{tabular}

* Mean and standard deviation.

lobe, colloids in follicles and the reticulum throughout the gland were also stained considerably with PAS reaction.

After the electrolytic injury of the basal tuberal or posterior median eminence region of the hypothalamus, conspicuous atrophy of basophils was observed in both lobes of pars distalis. The PAS positive basophils were markedly decreased in number and size and the cytoplasmic granules were scarsely observed (Table 3, Pl. VI-Figs. 2 and 5).

Table 3. Variation of cell population of PAS positive basophils in the middle sagittal plane of the adenohypophysis following the hypothalamic lesion.

\begin{tabular}{|c|c|c|c|c|}
\hline \multirow{3}{*}{ Site of lesion } & \multicolumn{4}{|c|}{ Cell population } \\
\hline & \multicolumn{2}{|c|}{ Cephalic lobe } & \multicolumn{2}{|c|}{ Caudal lobe } \\
\hline & Light & Deep & Light & Deep \\
\hline $\begin{array}{l}\text { PPM } \\
\text { HPM } \\
\text { nT } \\
\text { MM } \\
\text { Ext. H. } \\
\text { Controls }\end{array}$ & $\begin{array}{l}23.01 \pm 5.82 * \\
17.35 \pm 4.38 \\
22.86 \pm 7.11 \\
14.30 \pm 2.46 \\
34.51 \pm 9.33 \\
22.23 \pm 8.55\end{array}$ & $\begin{array}{c}129.23 \pm 26.34^{*} \\
62.97 \pm 20.06^{11} \\
83.32 \pm 19.35^{11} \\
43.54 \pm 21.40^{11} \\
142.19 \pm 31.27 \\
222.43 \pm 35.10\end{array}$ & $\begin{array}{l}18.47 \pm 3.20 * \\
16.36 \pm 2.87 \\
14.92 \pm 2.31 \\
10.02 \pm 2.66^{22} \\
20.79 \pm 5.30 \\
19.80 \pm 9.54\end{array}$ & $\begin{array}{c}118.83 \pm 21.76^{*} \\
\left.96.01 \pm 36.37^{2}\right) \\
89.22 \pm 27.76^{11} \\
69.06 \pm 18.20^{11} \\
162.72 \pm 43.05 \\
198.38 \pm 39.03\end{array}$ \\
\hline
\end{tabular}

* Mean and standard deviation. 1) Significant at $1 \%$ level. 2) Significant at $5 \%$ level.

\section{Microspectrophotometrical measurements}

\section{A) Two-wavelength method}

It is impossible to obtain the standard curve of the PAS positive materials because no ideal homogeneous contents were existed at the cytoplasm of the basophils in situ. But, the colloids in the follicle are supposed to contain the most homogeneous PAS positive materials of all adenohypophyseal components. In the present study, standard curve was obtained by transmission through the colloids in situ (Fig. 3). Absorption peak of the colloid was obtained at $560 \mathrm{~m} \mu$ wavelength. The another one beam necessary for twowavelength method showing a half value of the maximum extinction in the standard curve was obtained at $503 \mathrm{~m} \mu$ wavelength in this study. 


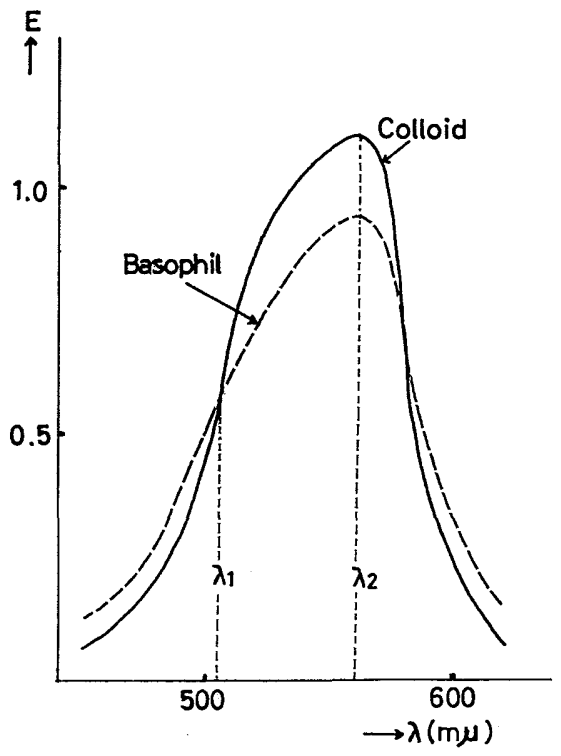

Fig. 3. Absorption curves of PAS positive materials in the adenohypophysis.

Absorption spectrum of glycoprotein microdroplets of basophils after the staining with the PAS reagents was shown in Fig. 3. The absorption peak in basophils was obtained at the $560 \mathrm{~m} \mu$ wavelength as same that in the colloid, but the extinction value was increased at $503 \mathrm{~m} \mu$ wavelength as compared with that in the colloid.

Relative amounts of PAS positive materials in basophils obtained by twowavelength method were shown in Table 4 and Fig. 4 . Basophils in adenohypophysis receiving the electrolytic injury at basal tuberal or posterior median eminence region in the hypothalamus contain about half or one third as much PAS positive materials (relative amount) as those in controls. These materials receiving the destruction at anterior or posterior hypothalamic region (PPM or HPM) are fairly stable, although individual variation is appreci-

Table 4. Average value of relative amount of PAS positive materials in 30 basophils distributed in the middle sagittal plane of the adenohypophysis by two-wavelength method.

\begin{tabular}{lcl}
\hline & \multicolumn{2}{c}{ Relative amount } \\
\cline { 2 - 3 } Site of lesion & Cephalic lobe & Caudal lobe \\
\hline PPM & $0.528 \pm 0.070^{*}$ & $0.497 \pm 0.066^{*}$ \\
HPM & $0.473 \pm 0.061^{2)}$ & $0.485 \pm 0.072$ \\
nT & $0.271 \pm 0.083^{1)}$ & $0.246 \pm 0.054^{1)}$ \\
MM & $0.284 \pm 0.045^{11}$ & $0.298 \pm 0.055^{1)}$ \\
Ext. H. & $0.602 \pm 0.082$ & $0.589 \pm 0.093$ \\
Controls & $0.604 \pm 0.079$ & $0.596 \pm 0.085$
\end{tabular}

* Mean and standard deviation. ") Significant at $1 \%$ level. 2) Significant at $5 \%$ level. 


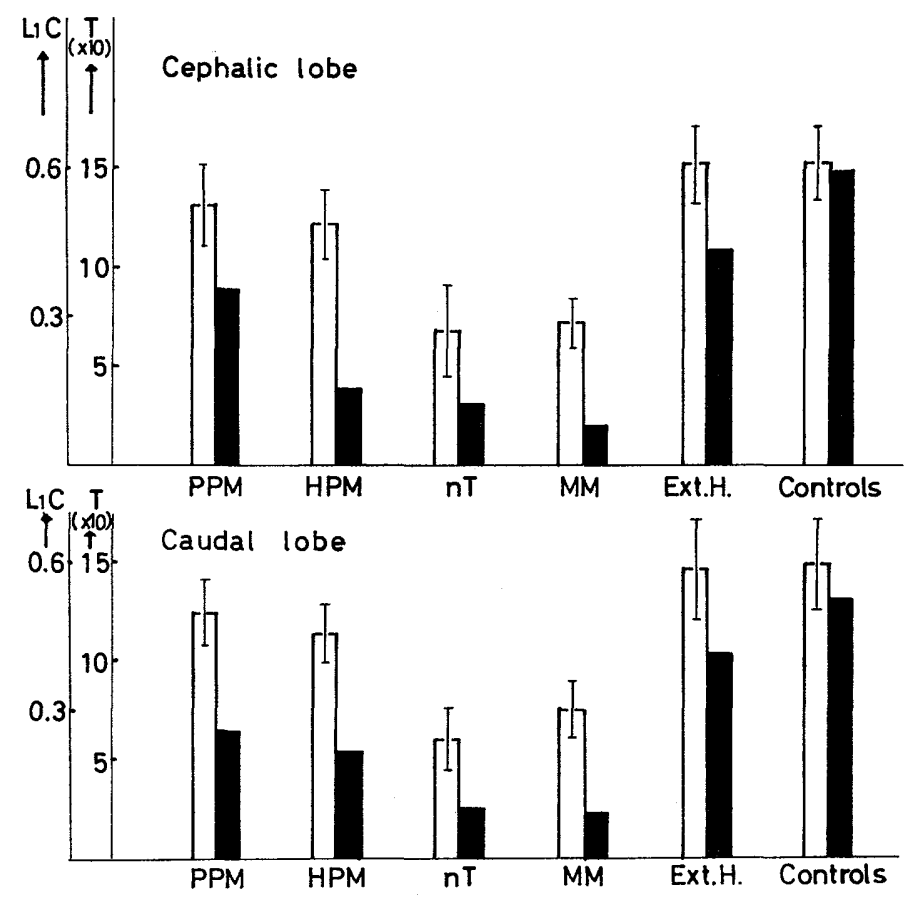

Fig. 4. Influence of hypothalamic lesion on the PAS positive materials in basophils as determined by relative and the total amount by twowavelength method. $\mathrm{L}_{1} \mathrm{C}, \square$; relative amount. $\mathrm{T}, \mathbf{\square}$; total amount (relative amount $\times$ basophil cell population).

able.

In consideration with the total amount, it appears that PAS positive contents are very low in adenohypophysis destroyed the basal tuberal or posterior median eminence region. Furthermore, in the lesioned birds destroyed posterior hypothalamic region, total amount of PAS positive materials in cephalic lobe decreased significantly, but showed no significance in caudal lobe. Destruction of preoptic (PPM) or extrahypothalamic area (Ext. H.) caused no remarkable effects of total amount of PAS positive materials in the adenohypophysis.

\section{B) Scanning method}

Four absorption curves of PAS positive basophils at different condition of the hypothalamic lesion were shown in Fig. 5. These curves were obtained by tracing with scanning spot in $1.6 \mu$ diameter at $560 \mathrm{~m} \mu$ wavelength in the basophils stained with PAS reaction. Cephalic and caudal basophils receiving the electrolytic injury at basal tuberal or posterior median eminence in the hypothalamus showed constantly low value of extinction and the smaller cell areas were obtained than those of the controls from the tracing curve.

Optical density, relative and the total amount of PAS positive materials in basophils by scanning method were shown in Table 5 and Fig. 6. Optical 
Table 5. Average value of optical density and the relative amount of PAS positive materials in 30 basophils distributed in the middle sagittal plane of the adenohypophysis by scanning method.

\begin{tabular}{lccccc}
\hline \multirow{2}{*}{ Site of lesion } & \multicolumn{2}{c}{ Cephalic lobe } & & \multicolumn{2}{c}{ Caudal lobe } \\
\cline { 2 - 3 } \cline { 5 - 6 } & Optical density & Relative amount & & Optical density & Relative amount \\
\hline PPM & $0.596 \pm 0.101^{*}$ & $75.0 \pm 10.2^{*}$ & & $0.540 \pm 0.165^{*}$ & $59.5 \pm 8.8^{*}$ \\
HPM & $0.584 \pm 0.136$ & $72.2 \pm 9.8$ & & $0.531 \pm 0.178$ & $\left.54.0 \pm 9.6^{2}\right)$ \\
nT & $0.329 \pm 0.092^{2)}$ & $25.7 \pm 7.4^{11}$ & & $\left.0.345 \pm 0.087^{2}\right)$ & $\left.23.8 \pm 5.0^{1}\right)$ \\
MM & $0.305 \pm 0.070^{2)}$ & $30.3 \pm 8.0^{11}$ & & $0.323 \pm 0.074^{11}$ & $27.3 \pm 6.3^{1)}$ \\
Ext. H. & $0.608 \pm 0.124$ & $82.3 \pm 11.4$ & & $0.620 \pm 0.121$ & $80.2 \pm 10.1$ \\
Controls & $0.623 \pm 0.148$ & $81.1 \pm 12.5$ & & $0.582 \pm 0.156$ & $76.4 \pm 9.8$ \\
\hline
\end{tabular}

* Mean and standard deviation. 1) Significant at $1 \%$ level. 2) Significant at $5 \%$ level.
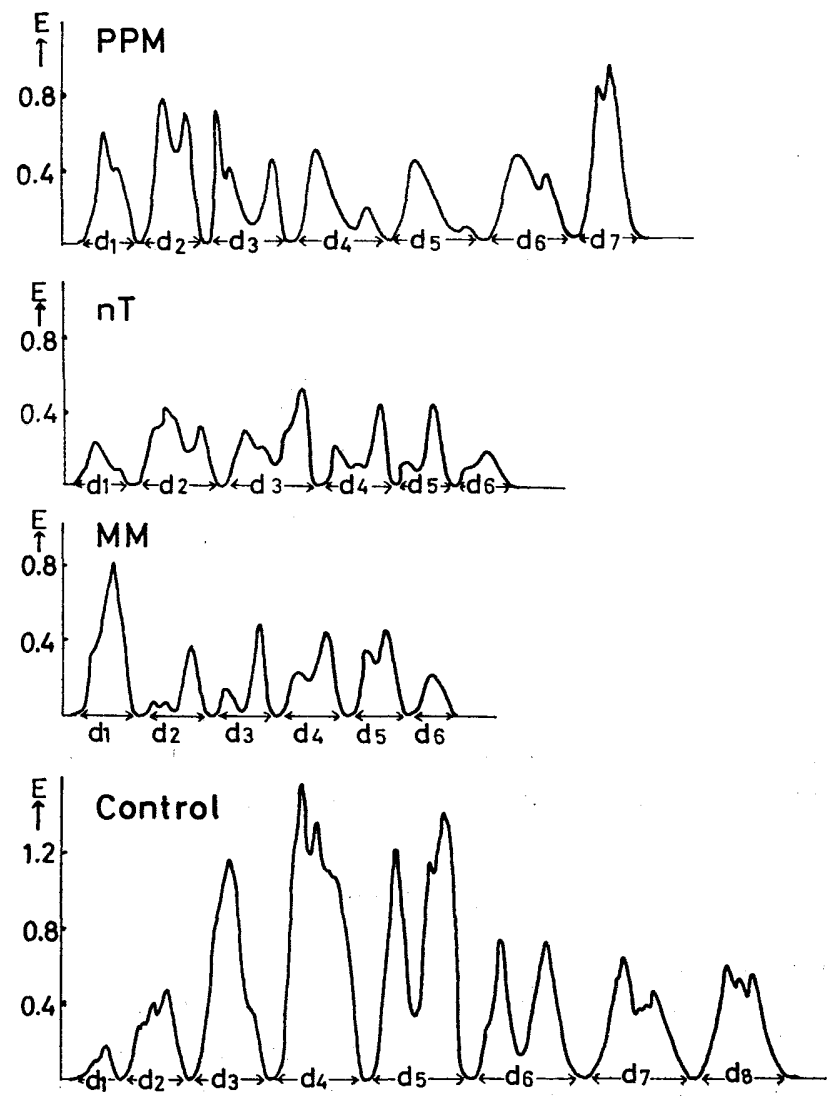

Fig. 5. Four examples of absorption curve at different condition of the hypothalamic lesion obtained by scanning method.

density was significantly decreased following the hypothalamic lesion at basal tuberal or posterior median eminence. Moreover, as shown in Fig. 5, these hypothalamic lesion caused to minimize the basophil cell area, the relative 

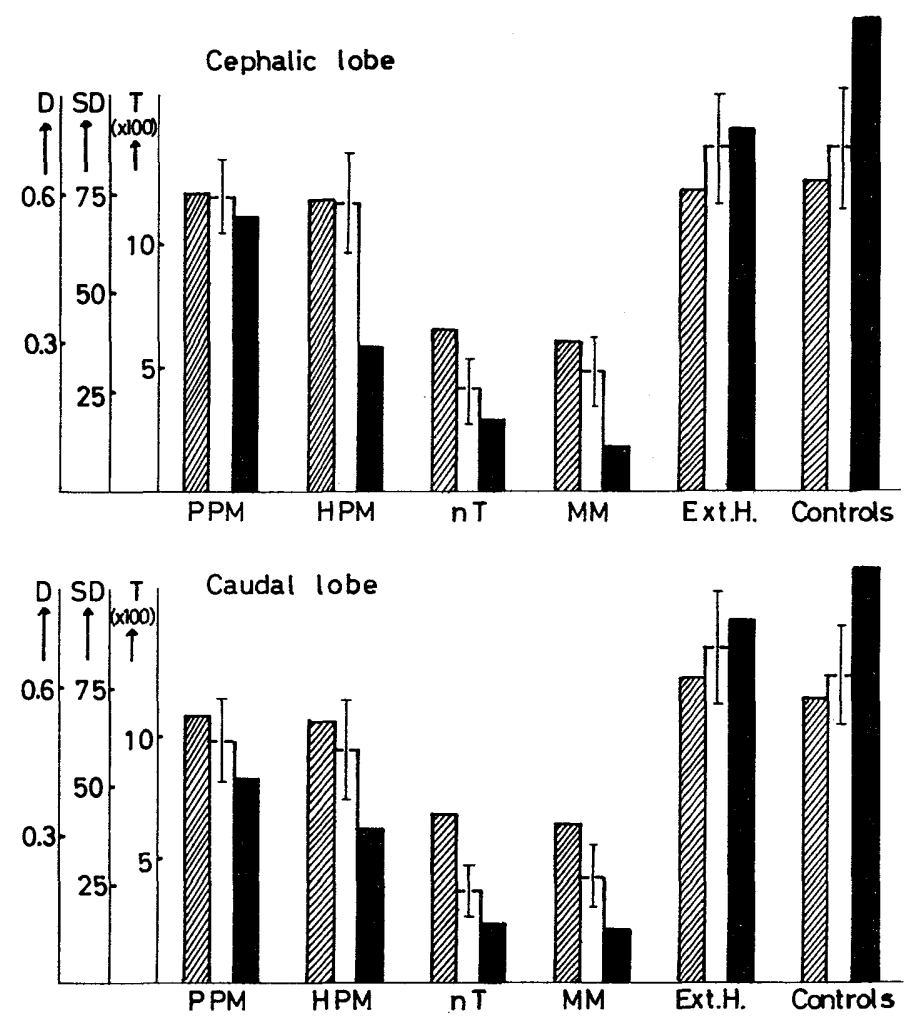

Fig. 6. Influence of hypothalamic lesion on the PAS positive materials in basophils as determined by optical density, relative and the total amount by scanning method. $\mathrm{D}$, 玹; optical density. SD, $\square$; relative amount (optical density $\times$ cell area). T, $\boldsymbol{\square}$; total amount $(\mathrm{SD} \times$ basophil cell population).

and total amount of PAS positive materials in basophils showed more obvious decrease resulting to acceleration of these effects.

\section{DISCUSSION}

The experimental lesion of the hypothalamus is one of the most extensively used means of studying the neural control of the endocrine system. It was thought, however, that it might be rewarding to look first into the consequences of hypothalamic lesion as reflected in the weight and histological state of endocrine glands.

After lesions involving the median eminence of the hypothalamus, gonadal atrophy has been reported in domestic fowls by Egge and Chiasson (1963), Lepkovsky and Yasuda (1966) and Graber et al. (1967). It has been concluded from the atrophic state of the testes and the accessory organs that gonadotropic hormone output from the adenohypophysis after the injury of the me- 
dian eminence must be at a impairment of neural and vascular connexions between adenohypophysis and the hypothalamus. It appears that there is no convincing evidence of gonadal atrophy except the destruction of capillary loop system of the median eminence. However, there can be little doubt that gonadal atrophy after lesion of the median eminence is caused not simply by the defective blood supply of the adenohypophysis, but by the disruption of a hormonal influence exerted by the hypothalamus on the adenohypophyseal tissue.

In this study, marked atrophy of adenohypophysis, testes and the accessory organs was observed after the basal tuberal or posterior median eminence lesion. In the previous experiment (Takahara et al., 1974b), histological changes were reported that gonadotropic basophils were very sparse and degenerated although a little number of normal basophils were presented in the adenohypophysis. The same tendency was reported in mammals by Bogdanove et al. (1955). The so-called "hypophyseotropic area" in the hypothalamus of mammals including arcuate-basal ventromedial nuclei region of the median eminence may be supposed to correspond to the basal tuberal and posterior median eminence region in cocks.

When the PAS reaction was applied to fowl adenohypophysis, basophils in both cephalic and caudal lobes were strongly stained with PAS reagent. Mikami (1958) reported that the cytoplasm of these basophils was contained glycoprotein and RNA as a result of application of various cytochemical techniques. Matsuo et al. (1969) classified the basophils of the White-Crowned sparrow into two types, light and deep, which could be distinguished with tetrachrome and PAS-methyl blue staining method. It is suggested that these two types of the White-Crowned sparrow may be involved in gonadotropic function since their appearance correlates well with the annual gonadal cycle and photoperiodic stimulation of gonadal growth and with the results of castration.

The gonadotropic function of basophils of the domestic fowl was suggested first by Kato and Nishida (1935) and subsequently confirmed by Kato (1938, 1939) with bioassays and cytological studies. Matsuo et al. (1969) postulated that light basophils of White-Crowned sparrow would be a correlation in functional cytology with the basophils in the fowl. In the previous study (Takahara et al., 1974a), light and deep basophils could be distinguished throughout the pars distalis in the adenohypophysis of cocks by staining method with PAS-Matsuo tetrachrome. These basophils may represent two functional phases of a single basophilic class of cells.

It seems generally agreed that the cephalic lobe of the avian pars distalis has a thyrotropic function (Payne, 1944; Mikami, 1955, 1958). However, there is a critical difference of opinion at the localization of thyrotrophs whether there are thyrotropic cells in both lobes (Yasuda, 1953; Tixier-Vidal, $1963,1965)$ or only in the cephalic lobe. It could not differentiate the basophils into gonadotrophs and thyrotrophs in the present cytological and cytochemical procedures. But, it is obvious that the basophil cell population and the PAS-positive materials in the cytoplasm of these cells markedly decreased 
following the electrolytic lesion of the basal tuberal or posterior median eminence region of the hypothalamus. The assumption may be considered that gonadotropic function in the hypothalamus is localized at basal tuberal or posterior median eminence region in White Leghorn cocks.

The PAS reaction is the basis of several differential staining methods for typing adenohypophyseal cells in mammals (Fand, 1955; Paget and Eccleston, 1960). FSH, LH and TSH have been demonstrated within these basophils by the pink to red color characteristic of PAS positive sites (Landing, 1957). The isolation of purified preparations of these hormones makes it possible to determine, in vitro, their chromogenic properties in the PAS reaction under conditions similar to those applied histochemically (Fand and Thorell, 1962).

The spectral characteristics of the colored products of the hormones can be applied to assess the PAS staining of adenohypophyseal cells in tissue sections by microspectrophotometry. Developments of the technique in the past decade give enough sensitivity and stability for accurately recording absorbency changes of 0.1 to 1.0 per cent from cell areas of $1.5 \mu$ in diameter (Chance et al., 1959; Pollister and Ornstein, 1959; Thorell and Åkerman, 1957).

Fig. 3 shows the absorption microspectrophotometric curves for the PAS positive structures together with similarly treated spectra from the experiment. The agreement is close between the microspectra and the absorption curves obtained by Fand and Thorell (1962) in human hypophysis. The absorption maximum and the general shape of the spectral absorption curves correspond to those obtained in human adenohypophysis. Also the rate of color development may behave similarly. The slight deviation at $503 \mathrm{~m} \mu$ can be expected from the effect of a distributional errors in the histological structures.

The two-wavelength method was clearly an improvement over one-wavelength techniques in that it reduced distributional error considerably and eliminated the laboriousness of measurements of the objects by using of an appropriate set of tables (Mendelsohn, 1958). Parallel refinements of scanning method in photometry were provided another solution for the distributional error problem. Thus the microspectrophotometrically obtained data in the present study will give a quantitative measure of PAS positive materials generated from the glycoprotein tropins by periodate oxidation in the basophil cell structure.

Relative amounts of PAS positive materials in basophil cells were decreased markedly following the electrolytic lesion of basal tuberal or posterior median eminence region in the hypothalamus. Comparison of these amounts per cell showed good agreement between the two methods employed as shown in Figs. 4 and 6. But, the effects of hypothalamic lesion on the total amounts of PAS positive materials (black column in Fig. 6) were more emphasized quantitatively at the scanning method than that in the two-wavelength method. This result was caused by the differences of measurement procedures such as the different selection of illuminated light spot dimensions, or the different assessment of irregular shaped cell area between the two method.

In any case, it is obvious that glycoprotein contents in basophil cells 
were significantly decreased after the hypothalamic lesion. There can be little doubt that the destruction of basal tuberal or posterior median eminence region of the hypothalamus causes a large impairment in the production of gonadotropin by the adenohypophysis in cocks.

\section{ACKNOWLEDGEMENT}

The author would like to acknowledge the continuing guidance and encouragement of Professor M. Okamoto, Laboratory of Animal Husbandry II, Faculty of Agriculture, Kyushu University.

\section{REFERENCES}

Bogdanove, E. M., B. N. Spirtos and N. S. Halmi 1955 Further observations on pituitary structure and function in rats bearing hypothalamic lesions. Endocrinol., 57: 302-315

Catchpole, H. R. 1949 Distribution of glycoprotein hormones in anterior pituitary gland of rat. J. Encocrinol., 6: 218-225

Chance, B., R. Perry, L. Ảkerman and B. Thorell 1959 Highly sensitive recording microspectrophotometer. Rev. Sci. Instr., 30: 735-741

Dahlqvist, A., I. Olsson and A. Norden 1965 The periodate-Schiff reaction; specifity, kinetics and reaction products with pure substrates. J. Histochem. Cytochem., 13: 423-430

Egge, A. S. and R. B. Chiasson 1963 Endocrine effects of diencephalic lesions in the White Leghorn hens. Gen. Comp. Endocrinol., 3: 346-361

Fand, S. B. 1955 The histochemistry of the human pituitary body. I. Preliminary report including a differentiation among the basophils of the anterior and posterior lobes. J. Clin. Endocrinol. Metab., 15: 685-692

Fand, S. B. and B. Thorell 1962 Spectrophotometry of the periodic acid-Schiff reaction with pituitary hormones in vitro and in histological sections. J. Cell Biol., 13: 239-247

Gahrton, G. and X. Yataganas 1976 Quantitative cytochemistry of glycogen in blood cells. Prog. Histochem. Cytochem., 9: 1-30

Graber, J. W., A. I. Frankel and A. V. Nalbandov 1967 Hypothalamic center influencing the release of LH in the cockerel. Gen. Comp. Endocrinol., 9: 187-192

Halmi, N. S. 1950 Two types of basophils in the anterior pituitary of the rat and their respective cytophysiological significance. Ecndocrinol., 47: 289-299

Halmi, N. S. 1952 Differentiation of two types of basophils in the adenohypophysis of the rat and the mouse. Stain Technol., 27: 61-64

Hotchkiss, R. D. 1948 A microchemical reaction resulting in the staining of polysaccharide structures in fixed tissue preparations. Arch. Biochem., 16: 131-141

Kato, Y. 1938 On the relations of anterior pituitary of fowl with production of the gonadostimulating hormone. Proc. Imp. Acad. Tokyo, 14: 233-236

Kato, Y. 1939 Functional significance of the cell types in the anterior pituitary of the fowl with special reference to the gonadostimulating hormone. Jap. J. Zootech. Sci., 11: 193-209 (Japanese with English summary)

Kato, Y. and S. Nishida 1935 Studies on the cytogenesis of the anterior pituitary in the fowl. Jap. J. Zootech. Sci., 8: 16-44 (Japanese with English summary)

Landing, B. H. 1957 Histochemical analysis of anterior pituitary cells of children, and the problem of correlation of cytoplasmic proteins with protein hormones. Lab. Invest., $6: 487-492$

Lepkovsky, S. and M. Yasuda 1966 Hypothalamic lesions, growth and body composition of 
male chickens. Poult. Sci., 45: 582-588

Matsuo, S. 1954 Studies on the acidophilic cells of the anterior pituitary in the fowl. Jap. J. Zootech. Sci., 25: 63-69 (Japanese with English summary)

Matsuo, S., A. Vitums, J. R. King and D. S. Farner 1969 Light-microscope studies of the cytology of the adenohypophysis of the White-Crowned sparrow. Z. Zellforsh., 95: 143176

McManus, J. F. A. 1948 Histological and histochemical uses of periodic acid. Stain Technol., 23: 99-108

McManus, J. F. A. and C. Hoch-Ligeti 1952 Modified periodic acid spot test for 1,2 glycols. Lab. Invest., 1: 19-23

Mendelsohn, M. L. 1958 The two-wavelength method of microspectrophotometer. II. A set of tables to facilitate the calculations. J.B.B.C., $4: 415-424$

Mikami, S. 1955 Cytochemical studies on the anterior pituitary of the fowl. II. The effects of the thyroidectomy and castration. Jap. J. Zootech. Sci., 26: 245-251 (Japanese with English summary)

Mikami, S. 1958 The cytological significance of regional patterns in the adenohypophysis of the fowl. J. Fac. Agr. Iwate Univ., 3: 473-545

Neumiller, G. and E. Vasseur 1953 The influence of $\mathrm{pH}$ on the periodate oxidation of carbohydrates. Ark. Kemi., 5: 235-245

Ornstein, L. 1952 The distributional error in microspectrophotometry. Lab. Invest., 1: 250262

Paget, G. E. and E. Eccleston 1960 Simultaneous specific demonstration of thyrotroph, gonadotroph and acidophil cells in the anterior hypophysis. Stain Technol, 35: 119-122

Patau, K. 1952 Absorption microphotometry of irregular-shaped objects. Chromosoma, 5: $341-362$

Payne, F. 1944 Anterior pituitary-thyroid relationships in the fowl. Anat. Rec., 88: 337350

Pollister, A. W. and L. Ornstein 1959 The photometric chemical analysis of cells. In "Analytical Cytology," 2nd edition, ed. by R. C. Mellors, Academic Press, New York, pp. 431-451

Purves, H. D. and W. E. Griesbach 1951 The site of thyrotrophin and gonadotrophin production in the rat pituitary studied by McManus-Hothchkiss staining for glycoprotein. Endocrinol., 49: 244-264

Purves, H. D. and W. E. Griesbach 1954 The site of follicle stimulating and luteinizing hormone production in the rat pituitary. Endocrinol., 55: 785-793

Purves, H. D. and W. E. Griesbach 1955 Changes in the gonadotrophs of the rat pituitary after gonadectomy. Endocrinol., 56: 374-386

Takahara, H., H. Iwamoto and M. Okamoto 1974a Microspectrophotometrical studies of the hypophysis in the domestic fowl (Gallus domesticus). I. Affinity of dyes and the absorption spectra in the adenohypophyseal cells. Sci. Bull. Fac. Agr., Kyushu Univ., 28: 203-213 (Japanese with English summary)

Takahara, H., H. Iwamoto and M. Okamoto 1974b Microspectrophotometrical studies of the hypophysis in the domestic fowl (Gallus domesticus). II. Effects of hypothalamic lesions on the reproductive function in White Leghorn cocks. Sci. Bull. Fac. Agr., Kyushu Univ., 29: 131-138 (Japanese with English summary)

Thorell, B. and L. Ákerman 1957 Recording microspectroscopy for the study of intracellular reactions. Exp. Cell Res., suppl., 4: 83-85

Tixier-Vidal, A. 1963 Histophysiologie de l'adénohypophyse des oiseaux. In "Cytologie de l'Adénohypophyse," ed. by J. Benoit and C. DaLage, Coll. Int. Centre Nat. Rech. Sci., No. 128 , pp. $255-274$

Tixier-Vidal, A. 1965 Caractéres ultrastructuraux des types ctllulaires de l'adénohypo- 
physe du Canard mâle. Arch. Anat. Micr. Morph. Exp., 54: 719-780

Utsumi, K. and S. Seno 1960 A quantitative study of the DNA content in the cell by microspectrophotometry. Symp. Cell Chem., 10: 221-232 (Japanese with English summary) Wilson, M. E. 1952 The embryological and cytological basis of regional patterns in the definitive epithelial hypophysis of the chick. Am. J. Anat., 91: 1-50

Yasuda, M. 1953 The two types of basophils in the fowl pituitary. Ach. Hist. Jap., 5: 327336 


\section{Explanation of Plate VI}

Fig. 1. Histological picture of a mock lesioned adenohypophysis. Normal acidophils (red) and basophils (light and deep) have been observed in the caudal lobe. Light basophils are round or oval in shape, their nuclei are large with distinct nucleoli. Deep basophils are polyhedral and much smaller than the light basophils. The cytoplasmic granules of these cells are coarse and have a strong affinity for methyl green. Matsuo tetrachrome stain. $\times 400$.

Fig 2. Cephalic lobe tissue of an adenohypophysis received electrolytic lesion of basal tuberal part in the hypothalamus. Most of basophils were markedly degenerated and showed a chromophobic appearance with fine granulation in the cytoplasm. Matsuo tetrachrome stain. $\times 400$.

Fig. 3. Caudal lobe tissue of a normal control adenohypophysis. Acidophils show a strong affinity for iron hematoxylin (black). PAS-Heiden hain's iron hematoxylin stain. $\times 400$.

Fig. 4. Caudal lobe tissue of a normal control adenohypophysis. Deep basophils have many coarse cytoplasmic granules showing a strong PAS positive reaction. Light basophils are also PAS positive with the fine granules. PAS stain. $\times 400$.

Fig. 5. Cephalic lobe tissue of an adenohypophysis received electrolytic injury of posterior median eminence region in the hypothalamus. PAS positive granules in the basophils decreased remarkably following the hypothalamic lesion. PAS stain. $\times 400$.

Fig. 6. Aspect of microspectrophotometric measurement by two-wavelength method. Single beam spot, $10 \mu$ in diameter, is lighted up the caudal basophil. The tissue was stained with PAS reaction. $\times 400$. 


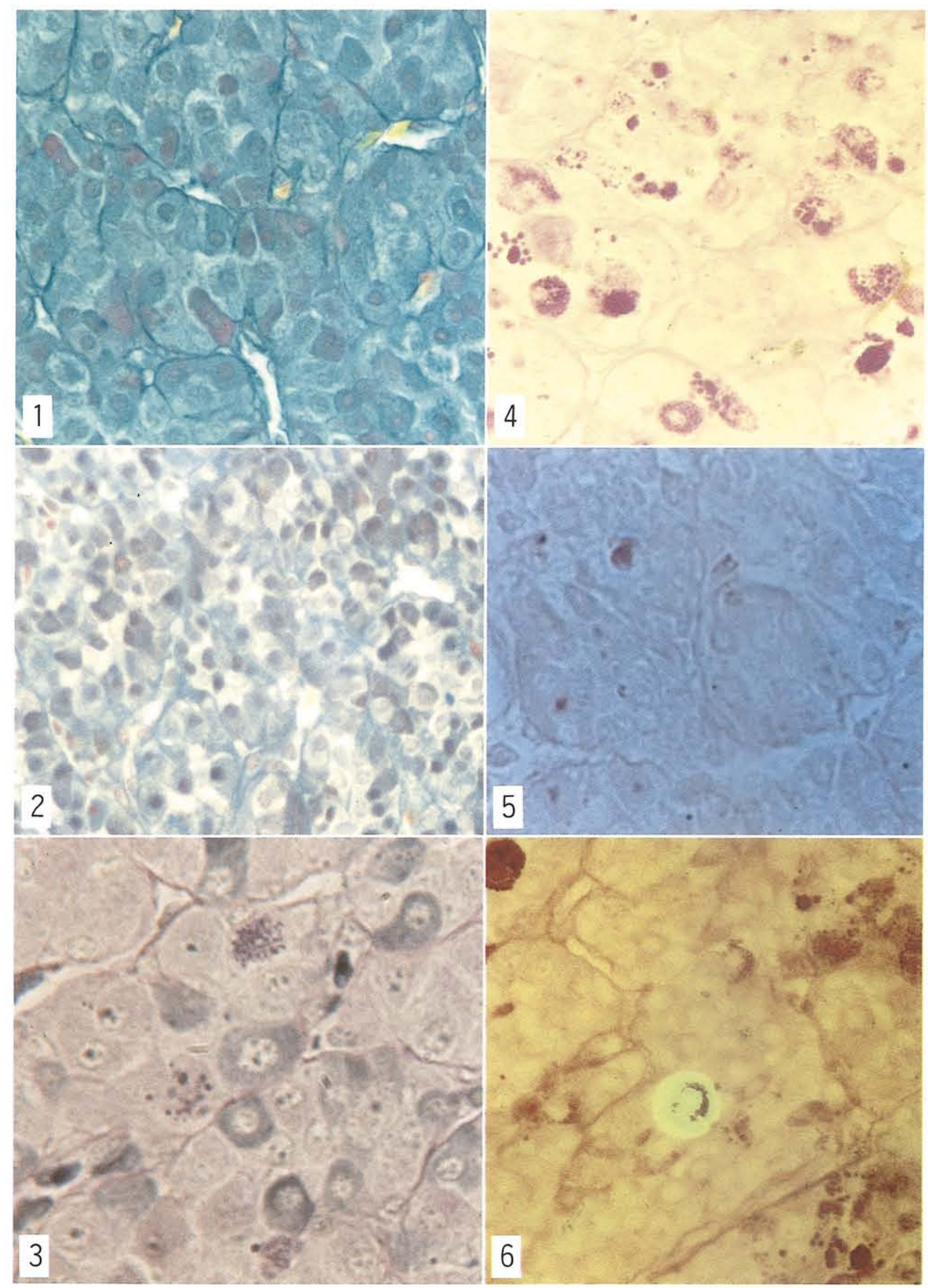

Microspectrophotometry of Hypophysis in the Fowl 